Article

\title{
Special Education Teacher Leadership in Jordan: Current State and Constraints
}

\author{
Eman Al-Zboon
}

Special Education Department, Queen Rania Faculty for Childhood, Hashemite University, Zarqa 13133, Jordan; emank@hu.edu.jo; Tel.: +962-7-900-6245

Academic Editor: Gregor Wolbring

Received: 17 May 2016; Accepted: 24 June 2016; Published: 29 June 2016

\begin{abstract}
Distributed leadership can enhance the professional learning communities of schools. The present study explored the leadership experience of Jordanian special education teachers, and their perceptions of common constraints to leadership. A mixed method design was used, including a survey $(n=136)$ and an interview $(n=23)$. Results indicated that special education teachers had little experience of leadership roles. They regarded the provision of cognitive and emotional support to colleagues as their most important leadership role, and participating in interview committees and selecting new teachers as the least important. There were no significant mean differences between male and female special education teachers in their level of enacted leadership. Level of education and years of experience were found to have a significant effect on the level of teachers' leadership.
\end{abstract}

Keywords: special education teacher; leadership; educational reform; perceptions

\section{Introduction}

The primary purpose of this paper is to explore the current state and constraints of special education (SE) teacher leadership (TL) in the context of Jordan. TL is a crucial component of any educational reform [1,2]. Teacher leadership refers to the right of teachers to play a vital role in the teaching process and in accomplishing learning outcomes [3]. In their study of restructured schools, Zigmond and colleagues [4] found that special educators' typical responsibilities went beyond co-teaching and co-planning, to "leadership roles in the weekly problem-solving meetings attended by school faculties and in the school-wide implementation and interpretation of curriculum-based assessments" (p. 11).

Promoting TL in schools might benefit teaching quality, specifically by enhancing instructional practices for proficient teachers. It will also encourage the sharing of best practices, working in collaboration with colleagues and guiding new teachers [5]. Leader teachers establish conditions that improve student outcomes [6], including the quality of classroom instruction and curriculum content, and the disciplinary climate in the school and the classroom.

The Jordanian national education strategy has emphasised the importance of engaging teachers, the local community, students and directors, to sustain and develop a supportive, healthy, safe and productive learning environment [7].

Bennettet et al. [8] stated that distributed leadership (DL) is not something "done" by an individual "to" others, or a set of individual actions through which people contribute to a group or organisation: "[it] is a group activity that works through and within relationships, rather than individual action" (p. 3). DuFour [9] and Harris [10] reported that recent reforms which engage teachers in the decision-making process or DL have demonstrated the need for enhanced teacher capacity in order for these reforms to improve student achievement. 


\section{Literature Review}

The education literature describes various forms of TL (team leader), association leader, department chair, supervisor and peer trainer [11,12]. The leader teacher may also take part in the process of decision-making at the level of school and directorates, performing a leadership role in the domains of curriculum, instruction, evaluation, new teacher selection, educational research and design and implementation of quality induction and mentoring programmes [13]. SE teacher leaders contribute to their schools, districts, and universities in a variety of ways, and SE teachers who have both the skills and the opportunities to collaborate often work with others in ways that are consistent with the role of a teacher leader [14]. Powers, Gregory, Lynas, McCracken, Watson, Boulton and Harris [15] reported good practice in the education of children with disabilities, where leadership emerged as a major factor.

Some cultural conditions of a school may facilitate TL, such as a school-wide focus on learning, inquiry, and reflective practice, encouragement for taking initiative, an expectation of teamwork and of sharing responsibility. Other cultural circumstances of schools and teaching profession standards, however, may limit the improvement of teacher leaders [5]. Variables that have the potential to inhibit TL include justice, privacy and autonomy [16]; egalitarianism and deference to seniority [17]; as well as the multiple responsibilities of the teacher, time, the level of cooperation or resistance of colleagues, and a focus on tests and maximising student scores [18].

The literature suggests numerous constraints to TL among SE teachers. Skrtic [19] indicates that SE teachers are often employed in bureaucratic organisations in which they work in isolation and have little control over important decisions. Other constraints include traditional hierarchical school structures, the high costs of working collaboratively, inadequate preparation for teacher leaders, lack of administrative support for new teacher roles, and stress among teacher leaders [5,11,20,21].

The traditional separation of special and general education, with differences in training and orientation between these two teacher groups, have contributed to the development of separate cultures [22]. Cultural differences include a traditional focus on legal bureaucracy and compliance in SE and instability in the SE teaching workforce; these are possible barriers to TL in SE [14]. Lieberman et al. [23] found that one of the main barriers to TL was often a feeling of being isolated from colleagues. Principals may also be less familiar with special educators' work than that of other teachers, which may prevent them from understanding the ways in which special and general educators might work together to contribute to leadership in schools [24].

Additionally, according to Al-Natour, Al-Zboon, Alkhamra and Amr [25], Jordanian SE teachers are constrained by other factors, including: large workload; high numbers of students in the classroom; and lack of pre- and in-service training.

The findings of a US study revealed no significant differences in the attitudes of male and female teachers towards leadership. Attitudes did differ, however, with regard to position. Of the various dimensions of TL, collaboration amongst teachers is considered the most important [26]. Ngang [27] investigated the TL style among SE teachers working in SE schools in Malaysia and China and found that they practised TL at high level. Harris and Muijs [28] detail a systematic literature review identifying extant research relating to TL. The findings illustrate that TL provides opportunities for collaboration and professional learning and positively affects school and classroom change. The main barriers to TL were found to be: Organisational Barriers, which are structural and result from the "top-down" leadership model that still dominates in many schools; and Professional Barriers, as teachers taking on leadership roles can sometimes be ostracised by their colleagues. Barth [18]; and Pankake and Moller [29] indicated that principals can support and influence the success of teacher leaders. In Macedonia, the Law on Primary Education explicitly and implicitly determines the leadership position of school teachers [30].

York-Barr et al. [31] conducted focus group interviews with SE teachers to examine "their realities of practice in inclusive education and to identify supports for such practice" (p. 193). They reported that special educators served as "informal leaders" (p. 200) who "articulated a sophisticated understanding 
of how their schools and districts functioned organizationally and politically" (p. 193). They also suggested that teacher leaders provided the vision, direction, and plans for SE and explained that teacher leaders collaborated and advocated across multiple levels within their educational systems to leverage social, structural and fiscal resources to the benefit of students with disabilities.

A Turkish study on the leadership styles of primary school teachers found that teachers usually adopted autocratic and repressive styles of leadership and that teachers with between one and ten years of tenure were more likely to exhibit authoritative, traditional leadership styles [32]. Toulabi, et al. [33] found that one of the essential components of teachers' quality of working life (QOWL) is involvement in decision-making. A study conducted with SE Arab-Palestinian teachers in Israel showed that involving teachers in schools is important in developing their work efficacy and well-being, and in decreasing learned helplessness [34].

However, it is worth pointing out that TL in Jordan would be different from that in other countries in the region because of contextual differences in culture, educational system, and teacher preparation programmes. It is vital for each community to have its own data on TL. Consequently, current findings from other countries might not be applicable to the educational context in Jordan.

\section{Jordanian Context}

The emergence of a reformation process for the Jordanian educational system has allowed a focus on TL. The reform agenda recognises the role of teachers and perceives them as the true engineers of change amidst reform [35]. His Majesty King Abdullah II launched the Association of QRA, which was recognised for excellence in education in 2005. It was considered a royal initiative with the vision of achieving creativity, knowledge management and excellence in the education environment. Honour, reward, and distinguished and creative teachers are central to the initiative. Her Majesty Queen Rania of Jordan launched the Teachers' Excellence Award in appreciation of the critical role of teachers as agents for change and reform in their schools [36]. However, this critical role is the core of TL.

The Education Reform for the Knowledge Economy Programme (ERfKE) (2002) is considered a multi-donor sector programme and was designed to convey the vision of the future for education in Jordan. This programme focuses on the school as the locus of control [37]. The Ministroy of Education (MoE) benefitted greatly from key contributors to Jordan, including the United States Agency for International Development (USAID), Canadian International Development Agency (CID), Microsoft, Cisco and the World Bank [38].

Services for children with disabilities in Jordan are implemented in numerous forms, including separated and inclusion programmes carried out by the MoE, community-based rehabilitation programmes, and daycare and internal residential SE centres carried out by the Ministry of Social Development (MoSD), the private sector and NGOs [39].

Since the declaration of the Salamanca Statement and Framework for Action on Special Needs Education in 1994, many countries have adopted inclusive practices for students with disabilities [40]. Yeung [41] reported that inclusive education can be successful when given strong leadership, promoting a collaborative school culture, fostering professional partnerships, and facilitating students' learning. In Jordan, in the integration phase, which began in the 1990s, students with disabilities were mainstreamed, or integrated into general education programmes when this was deemed appropriate [42].

\section{Significance of the Study}

Reform of our educational system in Jordan, through the adoption of the ERfKE, necessitates research to identify TL roles in SE. The teacher is central to the educational process. We need a law which honours and recognises those contributions and designates that leadership in a real way. SE TL in Jordan has not yet been evaluated. The roles of SE teachers appear "relatively limited and they often seem missing from school reforms because of a lack of understanding of their roles and functions" [43]. 
Rather than the typical emphasis of principal leadership in creating inclusive schools (e.g., [44,45]), Peters [46] emphasised the importance of the preconditions in the school and faculty involvement in changing the school culture. Lambert [47] states that "all teachers have the right, capability and responsibility to be leaders, therefore, the major challenge before us is not to identify who is and who is not a teacher leader but to create a context that evokes leadership from all teachers" (p. 422).

If given the opportunity, SE teacher leaders can help in numerous capacities to assure that the interests of students with disabilities are served [14]. Administrators should consider the statement by York-Barr et al. [31] that "recognizing, validating, and supporting the informal leadership work of SE teachers could go a long way in improving the quality of educational services for students with disabilities and other students as well" (p. 2).

The development of professional learning communities is imperative, creating opportunities for teachers, encouraging participation in leadership roles and fostering a strong relationship between teachers and principals [3]. In addition, Harris [10] states that the main trait of DL is cooperative working among teachers, with shared equipment.

The goal of building a professional learning community is student learning and, inevitably, the situation of students with disabilities calls for teacher involvement to help the students overcome feelings of despondency and futility [26]. York-Barr et al. [31] reported that the degree to which SE teachers are connected in a school influences the degree to which students with disabilities are connected, supported, and have opportunities within the school. If teachers are isolated and marginalised, their students are likely to be so as well. (p. 211). Leader teachers must work collaboratively and expand their knowledge and skills in order to successfully manage and retain students with disabilities [26]. If SE teachers had more influence in the workplace, they might be in a better position to solve some of their role problems [14].

\section{Statement of the Problem}

The body of literature on general education TL has increased rapidly over the past two decades [5,11]. However, research on the phenomenon of TL is still limited [6,30,32,48]. The leadership roles of SE teachers are infrequently referenced $[27,31,49]$. This gap in our knowledge is particularly significant at a time when educational restructuring is changing not only the tasks and behaviour of educational professionals, but also the conduct of professional relationships [50].

Harris [10] reported that the empirical evidence about DL is encouraging but far from conclusive. We need to know much more about the barriers, the unintended consequences and the limitations of DL (p. 18). In Jordan, traditional leadership is dominant and school principals and district administrations exhibit this kind of leadership. TL is considered a new concept in the Jordanian educational context. In addition, Jordanian teachers are underprepared in the field of leadership; pre-service and in-service programmes are scarce [51]. Al-Zboon et al. [52] investigated the level of QOWL of Jordanian SE teachers; results revealed that teachers rated participation in decision-making in school as the lowest item of a QOWL scale.

The current study is an initial step towards exploring SE TL roles in Jordan, and will contribute to the scarce existing literature on teachers as leaders in SE [53]. By examining SE TL roles and the ways in which teachers perceive such roles to be limited, insight will hopefully be gained into the challenges that teachers face in TL roles. The current study discusses practical TL applications to support education reform.

Based on the above information and consistent with reform of our educational system in Jordan, which considers the teacher as central to the educational process, the current study aims to investigate the leadership experience of Jordanian SE teachers by answering:

1. Which leadership roles do SE teachers favour?

2. What are the limitations to leadership encountered by SE teachers? 
3. Are there any significant differences in the perceptions of SE teachers regarding their leadership due to their gender, education level, years of experience, or type of school (mainstreaming and special education school)?

\section{Methodology}

\subsection{Research Design}

A mixed methods design, more specifically a sequential explanatory design, was adopted in the current study. Creswell [54] reports that this design contains two phases and is characterised by the collection and analysis of quantitative data followed by the collection and analysis of qualitative data. The priority is given to the quantitative part, with the purpose of the qualitative results being to further explore and explain the findings of a primarily quantitative study. The research procedure thus consisted of two phases. The first phase involved the collection of quantitative data via a survey examining teachers' views on leadership roles and factors hindering these roles. The second phase was qualitative, and consisted in a comprehensive investigation of how teachers perceive their leadership roles. Semi-structured interviews were conducted individually with SE teachers. Utilising mixed methods in social science research can help in counteracting weaknesses in both quantitative and qualitative research [55].

\subsection{Sample and Setting}

For the purpose of this study, the MoE in Jordan was contacted and asked to provide a list of the teachers and schools with SE services. Two teacher samples were selected to participate. The first sample was representative of the whole population of SE teachers in Amman (60\% of the total population). It consisted of $136 \mathrm{SE}$ teachers who hold full-time teaching positions in different MoE schools in the capital city of Jordan, Amman. Amman has the highest number of teachers and professional development services staff in Jordan. The data were collected during the academic year of 2014 to 2015. Participants were randomly selected. The original population was 265 SE teachers, which is the total number of teachers working in these schools.

Of the 136 participants, 60 were working as teachers of students with learning difficulties (LD) in mainstream schools. These teachers were teaching between 20 and 25 students with LD in resource rooms in regular schools. A mainstreaming school means a school where students with LD are educated in regular classes during specific time periods of day, as regular education classes are combined with a resource room. A resource room is a separate, remedial classroom where students are provided with direct, specialised instruction from SE teachers. There were 76 SE teachers working as teachers of students with sensory impairments (SI) in special schools. These teachers taught between seven and nine students with SI in special, separated schools (see Table 1).

Table 1. Distribution of Sample According to Gender, Education Level, and Years of Experience.

\begin{tabular}{ccc}
\hline- & Variable & N (\%) \\
\hline \multirow{2}{*}{ Gender } & Males & $30(22.1 \%)$ \\
& Females & $106(77.9 \%)$ \\
\hline \multirow{2}{*}{ Education level } & Diploma & $26(19.1 \%)$ \\
& Bachelor & $73(53.7 \%)$ \\
& Graduate studies & $37(27.2 \%)$ \\
\hline \multirow{2}{*}{ Years of experience } & $1-2$ & $25(18.4 \%)$ \\
& $3-10$ & $54(39.7 \%)$ \\
& More than 10 & $57(41.9 \%)$ \\
\hline \multirow{2}{*}{ Type of school } & Mainstreaming school & $57(44.1)$ \\
& Special school & $76(55.88)$ \\
\hline
\end{tabular}


All the SE teachers in MoE schools in Amman were listed in alphabetical order and then 181 teachers were randomly selected for this study. To solicit the participation of SE teachers, packets containing cover letters and survey instruments were mailed to 181 randomly selected participants. The questionnaires were completed and returned to the researcher in a sealed envelope. Four weeks after sending the survey, 136 of 181 questionnaires were returned to the researcher: a return rate of $76 \%$.

The second sample was a convenience sample drawn from the original sample of survey respondents. Andrews and Frankel [56] assert that convenience sampling is a suitable sampling technique in this kind of situation regarding feasibility and access to participants. There were $23 \mathrm{SE}$ teachers selected and individually interviewed at their schools. A group of teachers was selected, each teacher having met the following criteria: must be employed in the MoE school as a SE teacher in Amman; a minimum of one year teaching experience in MoE school with SE services; and both genders.

\subsection{Ethical Considerations}

Official ethical approval was obtained from the MoE. Participants were first contacted and invited to participate. They were informed of the aims of the study. Consent was obtained from the participants prior to beginning the research. Participants were assured of anonymity and confidentiality. The study was conducted under the ethical code of the International Review Board (IRB) at Hashemite University.

\subsection{Instrumentation}

\subsubsection{Survey}

The scale consisted of three parts. In part 1, teachers provided demographic information by checking applicable items. Part 2 consisted of 17 items designed to investigate TL. These were measured using a five-point Likert-type scale ranging from [5] "always" to [1] "never". Part 3 included ten items measuring factors SE teachers might perceive as barriers to leadership roles. Teachers were asked to indicate whether each item was perceived as a [1] "major constraint" or [2] "not a constraint" to TL.

To construct the survey of the present study, the following procedures were carried out:

- The researcher developed the scale and identified items based on the literature review (e.g., $[5,6,14,18,27,28,31,50]$. Initial versions of the TL subscale and constraints subscale were attained with 18 and 8 items, respectively.

- $\quad$ The researcher administered the proposed scale of study to an exploratory sample (ten of the SE teachers). The pilot study was designed to enable the researcher to: (a) examine the transparency of items and goodness-of-fit of the scale, and (b) improve the scale to ensure the overall acceptance of it by the respondents. The process provided insight into how each item was understood as well as the strategies used in formulating responses. Each respondent received the proposed scale and was asked to examine the scale items for clarity, suggest additions or deletions, and correct any errors in wording or procedures. Most of the suggestions were related to unfamiliar concepts, items considered irrelevant to these teachers' classroom situations. Suggestions from the pilot study were considered and some minor changes were made to the scale. Most of the changes included rewording and rephrasing of the scale items; no item was added or deleted. The wording structure of 11 items was reversed.

\subsubsection{Validity and Reliability}

In order to develop the validity of the survey, eight experts working as leaders in the educational field reviewed the scale and provided feedback. Their suggestions and comments were considered and changes made accordingly. The items were revised until all reviewers agreed on the words used and the content validity. Following the experts' suggestions, one item was deleted from the scale and two items were added. 
In order to improve construct validity, the Pearson correlation matrix was used. The correlation between scale items and total score was: 0.41 to 0.79 , which was significant at $p=0.05$, thus; the scale can be considered generally valid (see Table 2 ).

Table 2. Pearson correlation coefficient.

\begin{tabular}{cccc}
\hline & Leadership Roles & \multicolumn{2}{c}{ Constraints } \\
\hline Item Number & Item Correlation with Total Score & Item Number & Item Correlation with Total Score \\
\hline 1. & $0.79^{* *}$ & 1. & $0.62^{* *}$ \\
2. & $0.49^{*}$ & 2. & $0.54^{*}$ \\
3. & $0.67^{* *}$ & 3. & $0.72^{* *}$ \\
4. & $0.71^{* *}$ & 4. & $0.65^{* *}$ \\
5. & $-0.41^{*}$ & 5. & $0.43^{*}$ \\
6. & $0.65^{* *}$ & 6. & $0.75^{* *}$ \\
7. & $0.45^{*}$ & 7. & $0.63^{* *}$ \\
8. & $0.74^{* *}$ & 8. & $0.57^{*}$ \\
9. & $0.44^{*}$ & 9. & $0.55^{*}$ \\
10. & $0.77^{* *}$ & 10. & \\
11. & $0.59^{*}$ & & \\
12. & $0.70^{* *}$ & & \\
13. & $0.63^{* *}$ & & \\
14. & $0.61^{* *}$ & & \\
15. & $0.69^{* *}$ & & \\
16. & $0.55^{*}$ & & \\
\hline
\end{tabular}

* Significant $(p<0.05) ; * *$ significant $(p<0.01)$.

Reliability indices were determined by using Cronbach's alpha in a pilot study, in which the survey was administered to 16 teachers, who were not included in the final study sample. The coefficient alphas for the level of SE TL subscale and constraints subscale were 0.91 and 0.74 , respectively, reflecting good levels of internal consistency (Table 3).

Table 3. Reliability Score for Each Sub-Scale.

\begin{tabular}{ccc}
\hline Sub-Scale & Reliability Score & Number of Items \\
\hline Leadership roles & 0.91 & 17 \\
Constraints & 0.74 & 10 \\
\hline
\end{tabular}

\subsubsection{Semi-Structured Interview}

The researcher developed a semi-structured interview schedule based on five open-ended questions, including teachers' perceptions of TL, TL roles, and their views on TL constraints. Interviews took an average of $35 \mathrm{~min}$ each, and took place in the schools.

\subsubsection{Data Analysis}

Means, standard deviations, and modes were calculated, and statistical analysis was performed with an independent sample $t$-test for gender by one-way ANOVA for years of experience and education level, using the SPSS (Version 22) package.

All interviews were recorded and transcribed and their content was thematically analysed. The qualitative data on TL roles and the existing constraints were obtained by going through interviews and coding the data. These codes were revised using a constant comparative method [57]; the transcripts were then recoded according to these revised codes. The codes were then grouped into common themes to form categories and subcategories and the relevant quotes for these codes were placed within these groupings. Analysis of the interview data revealed two themes: (a) Levels of Leadership in SE teachers; and (b) Constraints Encountered by SE Teachers in Leadership Roles. 


\section{Integration of Findings}

\subsection{Levels of Leadership in Special Education (SE) Teachers}

Standard deviation and means were calculated in order to answer the first research question. Table 4 presents responses to the subscale that measures level of enacted leadership roles amongst teachers. Ranks were allocated to each item based on the order of the means. The total mean score for this scale was 1.9. Since the total mean score is below 2.0, SE teachers enact a low level of leadership roles. Teachers rated "providing cognitive and emotional support to colleagues" as a major leadership role; this was represented by a mean score of 3.4. By contrast, teachers rated "participating in interviewing committees and the selection of new teachers" as the leadership role they enacted least, with a mean score of 1.27 (Table 4 ).

Table 4. Means and Standard Deviations of Teachers' Perceptions of Leadership.

\begin{tabular}{|c|c|c|}
\hline Item & M (SD) & Rank \\
\hline $\begin{array}{l}\text { Providing cognitive and emotional support to colleagues (e.g., developing new ways } \\
\text { of thinking, training, suggesting new ideas \& helping in problem solving) }\end{array}$ & $3.4(1.23)$ & 1 \\
\hline Participating in professional development of colleagues & $2.77(1.24)$ & 2 \\
\hline Participating in the improvement of the school through initiating ideas and thoughts & $2.66(1.26)$ & 3 \\
\hline $\begin{array}{l}\text { Participating in guidance, follow-up, training or performance development of } \\
\text { new teacher }\end{array}$ & $2.65(1.38)$ & 4 \\
\hline Representing his/her school in meetings and conferences & $2.3(1.34)$ & 5 \\
\hline Working as a team leader & $2.22(1.38)$ & 6 \\
\hline Participating in decision process at the level of school or district & $1.69(1.07)$ & 7 \\
\hline Participating in the development teams at the level of schools and district & $1.67(1.094)$ & 8 \\
\hline $\begin{array}{l}\text { Performing leadership roles in an institute or organisation (such as teachers' council, } \\
\text { or teacher club or board) }\end{array}$ & $1.669(1.19)$ & 9 \\
\hline Participating in curriculum development teams & $1.66(1.027)$ & 10 \\
\hline Working as a trainer in training courses & $1.64(1.105)$ & 11 \\
\hline Working as vice principal or assistant & $1.61(1.019)$ & 12 \\
\hline $\begin{array}{l}\text { Participating in enhancement of the curriculum, instruction, and students' evaluation } \\
\text { at the level of the school }\end{array}$ & $1.58(1.0)$ & 13 \\
\hline Conducting scientific research & $1.5(0.987)$ & 14 \\
\hline Participating in the evaluation team of a certain institute, prize competition, or teachers & $1.419(0.91)$ & 15 \\
\hline Participating in shaping educational policies and rules & $1.28(0.66)$ & 16 \\
\hline Participating in interviewing committees and the selection of new teachers & $1.27(0.70)$ & 17 \\
\hline Total & $1.9(0.71)$ & \\
\hline
\end{tabular}

The interview data support the quantitative results presented in the first stage, and confirm that leadership roles are perceived as limited in scope and frequency. Most teachers, when asked whether they experience leadership roles, expressed their dissatisfaction with the frequency and extent of these leadership roles, describing them as insufficient and in need of improvement. The following excerpts exemplify participant sentiment on these issues. Shadia ${ }^{1}$ said: "It is very limited and happens at a low level."

Muna commented that "There are very little instances of leadership roles which are not sufficient at all."

$1 \quad$ All names are pseudonyms. 
Laila responded: "Teacher leadership?! The principal is the person who carries leadership responsibility within schools."

According to Sami: "Leadership requires formal power and authority. However, SE teachers don't have this power."

Ahmad noted that: "SE teachers often do not seem to practise leadership roles, both inside and outside the school setting."

Maha elaborated, saying: "Teachers' roles are evolving recently because of educational reform in Jordan. Unfortunately, SE teachers have little involvement in leadership roles."

Two teachers expressed the view that leadership roles occur at a good level. However, in-depth examination of participants' answers indicates that their understanding of leadership was simplistic and incomplete. From their perspective, responsibility for the school morning programme, canteen or theatre constitutes leadership. For example, Fatima stated that: "I play leadership roles. For example, I attended a workshop about inclusion last year." Tamer also related his own experience, saying: "I enact leadership roles within my school; I always send school mail to the MoE".

\subsection{Constraints Encountered by SE Teachers in Leadership Roles}

Mode was calculated in order to answer the second research question. Findings indicate that teachers perceived there to be many barriers to the leadership roles they wished to enact. Teachers rated seven items as major constraints, with a mode score of 1 . These items were: lack of time to practise leadership roles; absence of laws and regulations related to teacher leadership; lack of pre-service training; lack of in-service training; negative attitudes towards SE teachers; overload of responsibilities and role dissonance; and lack of communication opportunities within MoE. Meanwhile, teachers rated three items as "not constraints", with a mode score of 2. These items were: lack of administrative support; lack of leadership characteristics; and lack of communication opportunities within school (Table 5).

Table 5. Modes of Teachers Rating of Constrains.

\begin{tabular}{cc}
\hline Item & Mode \\
\hline Lack of time to practice leadership roles & 1 \\
Absence of laws and regulations related to teacher leadership & 1 \\
Lack of pre-service training & 1 \\
Lack of in-service training & 1 \\
Negative attitudes towards SE teachers & 1 \\
Overload of responsibilities and role dissonance & 1 \\
Lack of communication opportunities within MoE & 1 \\
Lack of administrative support & 2 \\
Lack of leadership characteristics & 2 \\
Lack of communication opportunities within school & 2 \\
\hline
\end{tabular}

Interview transcript analysis indicated that the most frequent constraints were lack of training and workload, indicated by $65 \%$ and $52 \%$ of the teachers, respectively. An additional constraint reported by SE teachers was gender-related barriers to leadership roles $(8.6 \%)$. Some of the constraints that teachers noted are expressed in the following selected excerpts: "There isn't a sufficient preparation related to TL. There aren't any training courses specialised on TL, neither in pre-service programmes nor in in-service programmes" (Muna); "We are loaded with instruction schedules. We have many classes every day to teach in addition to other duties like exhausting paperwork and administrative work" (Rami). 


\subsection{Impact of Variables on Teacher Leadership (TL)}

Independent $t$-tests were conducted to investigate whether the gender of teachers affected their perceptions of TL. There were no statistically significant mean differences between male and female SE teachers on perceptions of TL levels $(t=-0.89, p<0.37)$ or constraints to TL $(t=1.6, p<0.11)$.

The influence of education level on leadership subscale score was investigated using a one-way ANOVA, and was found to exert a significant effect $(F=4.95, p=0.008)$. To discover the source of these differences, the Scheffé test for post hoc comparisons was computed. Results indicated that differences between the second (bachelor degree) and third level of education (graduate studies) were significant (Tables 6-8).

Table 6. Mean and Standard Deviation of Teachers' Perceptions of Leadership According to Education Level.

\begin{tabular}{cccc}
\hline Education Level & N & Mean & SD \\
\hline Diploma & 26 & 2.0814 & 0.78886 \\
Bachelor & 73 & 1.7623 & 0.62060 \\
Graduate studies & 37 & 2.1618 & 0.76378 \\
Total & 136 & 1.9315 & 0.71439 \\
\hline
\end{tabular}

Table 7. F-test of the Effect of Education Level on Teachers' Perceptions of Leadership.

\begin{tabular}{cccccc}
\hline Differences & Sum of Squares & Df & Mean of Squares & $F$-Value & $p$-Value \\
\hline Between groups & 4.556 & 2 & 2.278 & 4.95 & 0.008 \\
Within groups & 63.321 & 131 & 0.483 & - & - \\
\hline Total & 67.877 & 133 & - & - & - \\
\hline \multicolumn{5}{c}{ Note: degrees of freedom (Df). }
\end{tabular}

Table 8. Post Hoc Tests Multiple Comparisons.

\begin{tabular}{|c|c|c|c|c|c|c|c|}
\hline \multirow{2}{*}{$\begin{array}{l}\text { Dependent } \\
\text { Variable }\end{array}$} & \multirow{2}{*}{$\begin{array}{c}\text { Educational } \\
\text { Level }\end{array}$} & \multirow{2}{*}{ Educational Level } & \multirow{2}{*}{$\begin{array}{c}\text { Mean } \\
\text { Difference }\end{array}$} & \multirow{2}{*}{$\begin{array}{l}\text { Std. } \\
\text { Error }\end{array}$} & \multirow{2}{*}{ Sig. } & \multicolumn{2}{|c|}{ 95\% Confidence Interval } \\
\hline & & & & & & Lower Bound & Upper Bound \\
\hline \multirow{6}{*}{ Total } & \multirow{2}{*}{ Diploma } & Bachelor & 0.34821 & 0.34653 & 0.605 & -0.5133 & 1.2097 \\
\hline & & Graduate studies & -0.08032 & 0.17894 & 0.654 & -0.4343 & 0.2737 \\
\hline & \multirow{2}{*}{ Bachelor } & Diploma & 0.34821 & 0.34653 & 0.605 & 1.2097 & -0.5133 \\
\hline & & Graduate studies & $-0.39951 *$ & 0.14192 & 0.006 & -0.6803 & -0.1188 \\
\hline & \multirow{2}{*}{$\begin{array}{l}\text { Graduate } \\
\text { studies }\end{array}$} & Diploma & 0.08032 & 0.17894 & 0.654 & -0.2737 & 0.4343 \\
\hline & & Bachelor & $-0.39951 *$ & 0.14192 & 0.006 & 0.1188 & 0.6803 \\
\hline
\end{tabular}

* The mean difference is significant at the 0.05 level.

ANOVA revealed significant differences attributable to years of experience on the total score for the leadership subscale for SE teachers $(F=7.33, p=0.001)$. The Scheffé test for post hoc comparisons was computed. Results indicated that these differences were between the first (one to two years) and the third level (three to ten years), and between the second (three to ten years) and the third level (more than ten years) of experience (Tables 9-11). 
Table 9. Mean and Standard Deviation of Teachers' Perceptions of Leadership According to Years of Experience.

\begin{tabular}{cccc}
\hline Years of Experience & N & Mean & SD \\
\hline $1-2$ & 25 & 1.7506 & 0.62375 \\
3-10 & 54 & 1.7392 & 0.53161 \\
More than 10 & 57 & 2.1943 & 0.82238 \\
\hline Total & 136 & 1.9315 & 0.71439 \\
\hline
\end{tabular}

Table 10. F-test of the Effect of the Number of Years of Experience on Teachers' Perceptions of Leadership.

\begin{tabular}{cccccc}
\hline Differences & Sum of Squares & Df & Mean of Squares & $\boldsymbol{F}$-Value & $\boldsymbol{p}$-Value \\
\hline Between groups & 6.647 & 2 & 3.323 & 7.33 & 0.001 \\
Within groups & 61.230 & 131 & 0.467 & - & - \\
\hline Total & 67.877 & 133 & - & - & - \\
\hline
\end{tabular}

Table 11. Post Hoc Tests Multiple Comparisons.

\begin{tabular}{|c|c|c|c|c|c|c|c|}
\hline \multirow{2}{*}{$\begin{array}{l}\text { Dependent } \\
\text { Variable }\end{array}$} & \multirow{2}{*}{$\begin{array}{c}\text { Years of } \\
\text { Experience }\end{array}$} & \multirow{2}{*}{$\begin{array}{c}\text { Years of } \\
\text { Experience }\end{array}$} & \multirow{2}{*}{$\begin{array}{c}\text { Mean } \\
\text { Difference (I-J) }\end{array}$} & \multirow{2}{*}{$\begin{array}{l}\text { Std. } \\
\text { Error }\end{array}$} & \multirow{2}{*}{ Sig. } & \multicolumn{2}{|c|}{ 95\% Confidence Interval } \\
\hline & & & & & & Lower Bound & Upper Bound \\
\hline \multirow{6}{*}{ Total } & \multirow{2}{*}{$1-2$} & $3-10$ & 0.01141 & 0.16588 & 0.945 & -0.3167 & 0.3396 \\
\hline & & More than 10 & $-0.44374 *$ & 0.16445 & 0.008 & -0.7691 & -0.1184 \\
\hline & \multirow{2}{*}{$3-10$} & $1-2$ & -0.01141 & 0.16588 & 0.945 & -0.3396 & 0.3167 \\
\hline & & More than 10 & $-0.45515^{*}$ & 0.13102 & 0.001 & -0.7143 & -0.1960 \\
\hline & More than & $1-2$ & 0.44374 * & 0.16445 & 0.008 & 0.1184 & 0.7691 \\
\hline & 10 & $3-10$ & $0.45515^{*}$ & 0.13102 & 0.001 & 0.1960 & 0.7143 \\
\hline
\end{tabular}

${ }^{*}$ The mean difference is significant at the 0.05 level.

Finally, with regard to type of school, independent sample $t$-tests were conducted. The results of the $t$-tests revealed no statistically significant mean differences between teachers working in mainstreaming and SE schools on TL $(t=-1.866, p<0.834)$.

\section{Discussion}

According to Harris and Jones [58], DL has the ability to enhance the professional learning communities of schools. Lieberman and Miller [59] call for the development and nurturing of TL as a critical component of distributed leadership. The aim of this study was to explore levels of Jordanian SE TL and the constraints teachers perceive as hindering their leadership efforts. Both quantitative and qualitative findings demonstrated that SE teachers reported a low level of leadership. This is consistent with Al-Zboon et al. [52], who demonstrated that Jordanian SE teachers rated participation in decision-making in school as the lowest item of a QOWL scale. This finding contradicts those of different countries; for example, Ngang [27] reported that SE teachers in China and Malaysia practise leadership roles at high levels. The current findings also contradict those of Petrovska and Sivevska [30], who reported that teachers in the Republic of Macedonia have the opportunity to manifest their leadership competencies in several areas of school life. However, these differences between Jordan and Macedonia might be explained by the unique type of teachers in our sample, SE teachers. Billingsley [14] reported that possible barriers to TL in SE include cultural differences between special and general education, a traditional focus on legal compliance in SE, and instability in the SE teaching workforce.

From a distributed leadership perspective, the practice of leadership is integrally bound up with the wider system in which it occurs; structural and situational factors are "constitutive" elements 
of leadership practice [60]. However, several barriers, such as lack of time and caseload [18,61] may hinder Jordanian SE teachers from enacting leadership roles. According to Cook and Downing [62], we are not preparing people with the necessary communication skills to work together efficiently. Myths about leadership, such as viewing leadership as something that exceeds the responsibilities of educators, may be a primary barrier to teachers viewing themselves as leaders [63]. According to Silva et al. [64], administrators and professionals who do not hold teaching responsibilities assume most leadership responsibilities. SE teachers often work under a dense bureaucracy, are usually not supported and exert minimal power over the decisions they need to take [19]. Research on TL in SE is needed to advance the work of teacher leaders in schools [14].

The education literature discusses a vital technique to improve TL. This technique is supported by all stakeholders, including principals [65,66], colleagues [5], district officers, and academicians from higher education institutions [27]. However, until some of the other role problems that have plagued SE are addressed, special educators may be overwhelmed by the idea of leadership [14].

Results also revealed that teachers rated "providing cognitive and emotional support to colleagues" as a major leadership role they practice. This finding resonates with those of Smylie and Denny [67], who mentioned that teachers often describe the role of teacher leaders as "primarily around functions of helping and supporting colleagues to fulfil classroom responsibilities and improved practice" (p. 244). The provision of support for teachers to develop as leaders may be a crucial component of leadership advancement [68]. Experienced teachers may work as mentors who guide teachers in their leadership responsibilities and offer psychological support [69]. The literature emphasises that TL is not just concerned with teachers developing individually, but a central role of teacher leaders is one of helping colleagues to try out new ideas and encouraging them to adopt leadership roles [23]. Harris [70] reported that the most important dimension of the TL role is forging close relationships with other individual teachers, through which mutual learning takes place.

Participation in interviewing committees and the selection of new teachers was regarded as the lowest leadership role. Leadership may be new to teachers and they may therefore not participate in its full range of roles: specific legislation may be required to promote these roles during the professional development of teachers.

Interview transcript analysis indicated that teachers' understanding of leadership was simplistic and incomplete. This result is in line with Katyal and Evers [71], who reported that teachers' understanding of leadership was simplistic within the educational systems. This may be due to the modernity of this concept in the Jordanian educational system.

Teachers rated seven factors as constraints to TL: lack of time to practise leadership roles; absence of laws and regulations related to TL; lack of pre-service training; lack of in-service training; negative attitudes towards SE teachers; overload of responsibilities and role dissonance; and lack of communication opportunities within the MoE. These constraints mirrored those reported elsewhere in the literature (e.g., $[5,11,14,20,21,23])$.In addition, this finding is supported by the study of Al-Natour et al. [25], which indicated that Jordanian SE teachers were constrained by their heavy workload, high numbers of students in the classroom, and lack of pre- and in-service training.

Teachers rated the lack of pre-service training as one of major constraints to leadership. This result is not unexpected, since teachers require sufficient training to instil in them leadership knowledge and skills [72]. This is not provided to teachers in Jordan. This finding is supported by the literature which discusses the insufficient preparation of teacher leaders $[5,11,20,21]$. The lack of well-qualified special educators also represents a potential TL barrier [26].

Teachers were dissatisfied with their professional preparation, and felt unprepared to assume leadership roles whilst dealing with students with disabilities [26]. Teacher leaders need adequate preparation, and this fact is often neglected [72]. These findings are inconsistent with those of some previous research (e.g., [62]), which indicated that SE teachers are well prepared to perform collaborative roles as teacher leaders. In this matter, Hanuscin et al. [63] found that although the participating teachers were involved in leadership experiences, most of them were doubtful about 
their roles as leaders. The results indicated that teachers are most likely to view themselves and their peers as leaders when they are engaged in activities pertaining to participation in pre-service teacher education activities.

Interview transcript analysis indicated that one of the most frequent constraints was workload. This finding is supported by the study of Al-Natour et al. [25], which indicated that Jordanian SE teachers are constrained by a heavy workload and large numbers of students in the classroom. Moreover, these time-consuming tasks often interfere with special educators' instructional responsibilities and contribute to role conflict, ambiguity, and stress [14].

Surprisingly, the results of this study suggest that lack of leadership characteristics was not seen as a significant factor hindering leadership. SE teachers in Jordan might believe that leadership entails qualities and skills that can be taught rather than representing an innate quality. By contrast, Hanuscin et al. [63] argue that not everyone can be a leader.

Educators suggest various ways to overcome these barriers. For instance, gaining an understanding of how teachers perceive leadership roles and the norms of their profession was suggested by York-Barr and Duke [5] as an initial strategy. Another way to overcome the barriers to leadership in teachers is to provide them with the necessary preparation and resources [72]. However, Harris [10] stated that "We need to know the limitations and pitfalls as well as the opportunities and potential of DL practice" (p. 18).

Male and female SE teachers did not differ significantly in the leadership roles they assumed. This is consistent with Katkat [73], who demonstrated that, in Turkey, TL capability is independent of gender. Other research suggests that female teachers are more likely to initiate leadership roles, especially when dealing with students who suffer pain and deprivation [26]. According to Shakeshaft et al. [74]: "Being born female or male does not in itself affect how we will act as workers; however, the way we are treated from birth onward, because we are either female or male, does help to determine how we both see and navigate the world" (p. 134).

This may be attributable to the fact that, in Jordan, males and females work in the same context and face the same circumstances. Jordanian public schools tend to be characterised by a principal-led style of leadership. Another possible explanation is that men and women describe leadership differently. Women are more likely to be more interactive as leaders, and men more traditional [75]. This should therefore be taken into consideration when designing surveys on the broad spectrum of leadership roles in men and women.

However, we need more in-depth study related to gender differences in TL. Lather [76] concluded that gender is central to understanding the distribution of power: Feminism argues the centrality of gender in the shaping of our consciousness, skills, and institutions as well as in the distribution of power and privilege. This is not to deny the powerful shaping forces of race, class, and sexual orientation; increasingly, feminist inquiry looks to the interaction of such social forces in the construction of our lives (p. 91).

Results revealed statistically significant differences in total leadership score as a function of education level. Differences were between the second (bachelor degree) and third (graduate studies) level of education. This is anticipated, as teachers with higher education levels may have been exposed to a greater number of leadership experiences, making them more proficient in leadership roles. According to Rutherford [77], the title of Lead Teacher is usually reserved for teachers who have at least three years of experience and have earned or are in the process of earning a graduate degree.

The current findings suggest that significant differences are due to years of experience in SE teachers. Billingsley [14] proposed that school districts capitalise on experienced special educators. The importance of experience in defining Lead Teachers may be due to that fact that experienced teachers can provide useful information through modelling teaching strategies, guiding and mentoring teachers and offering the psychological and emotional support teachers may require [69]. Beginner teachers, by contrast, might merely be struggling to survive in the profession during their first period of teaching [14]. 
Finally, with regard to type of school, the results revealed no statistically significant differences between teachers working in mainstreaming and SE schools on TL. This finding was reasonable, given that these schools have similar circumstances as they are all public governmental schools. Skrtic's research [19] indicated that SE teachers often work in bureaucratic organisations where teachers do not, indeed, have an active role in important decisions. This result concurs with the study of Al-Zboon et al. [52], which indicated no significant differences between teachers working in mainstreaming and SE schools in the decision-making domain.

\section{Conclusions}

The results of this study are important in understanding the current state of special education (SE) teacher leadership (TL) in Jordan and elsewhere. Teachers regard themselves as inhabiting low-level leadership roles. Results also indicated many barriers to TL: lack of time to practise leadership roles; absence of laws and regulations related to TL; lack of pre-service training; lack of in-service training; negative attitudes towards SE teachers; overload of responsibilities and role dissonance; and lack of communication opportunities within the Ministry of Education (MoE). The study emphasises the need for complete reformation of SE teacher preparation programmes, neither exclusively pre-service nor in-service. These programmes should enhance leadership among teachers. In addition, schools should provide teachers with opportunities to practise leadership roles. Furthermore, Jordanian policy should require that teachers, by law, hold leadership roles, in order to improve the position of the SE teacher profession and the teachers' quality of working life (QOWL) for teachers.

\subsection{Implications}

The research questions investigated here are especially important for the new interest in TL. The findings suggest an urgent need for teacher preparation programmes to include the topic of SE TL in their pre-service preparation and training, to equip teachers with a wide range of leadership roles. Moreover, this study encourages research in SE leadership and calls for a change in the role of SE teachers from service providers to potential leaders in the education process.

The MoE should recognise TL as a vital domain through its in-service training programmes and workshops and by directing efforts to minimise obstacles facing teachers in leadership roles. Additionally, we can benefit from other countries' experiences in the field of programmes that foster TL, such as the New Teacher Center, and the Teacher Learning and Leadership Programme in Canada [78].

Policy-makers should reconsider the leadership roles available to teachers, and work to increase the support that concerned groups can and should provide for teachers to assume leadership roles. Principals must introduce radical changes to school organisation, especially with regard to the introduction of participatory and distributed leadership.

\subsection{Limitations}

It is important to consider the findings of this study in the context of its limitations. The study sample and SE alternatives in the capital city of Jordan, Amman, during the academic year of 2014/2015, reduce the generalisability of the findings. Furthermore, this study was restricted by the limitations of the mixed method design, which appear mainly in the manipulation or reduction of the data and the compromises in sample size [79].The main method of data collection was a self-report questionnaire on how teachers perceive leadership. Future studies might address this limitation by using different resources to collect data-such as focus groups-and by collecting data from other concerned groups, such as supervisors, principals, district officers, academicians, undergraduate students and teachers in settings other than Jordan.

Acknowledgments: I thank Aieman Ahmad Al-Omari (Hashemite University) for his suggestions and comments on the manuscript.

Author Contributions: Eman Al-Zboon did all the required procedures of the research. 
Conflicts of Interest: The author declares no conflict of interest.

\section{References}

1. Clemson-Ingram, R.; Fessler, R. Innovative programs for teacher leadership. Action Teach. Educ. 2014, 19, 95-106. [CrossRef]

2. Fleming, P. Successful Middle Leadership in Secondary Schools: A Practical Guide to Subject and Team Effectiveness; Routledge: Oxon, UK, 2014.

3. Childs-Bowen, D.; Moller, G.; Scrivner, J. Principals: Leaders of leaders. Natl. Assoc. Second. Sch. Princ. Bull. 2000, 84, 27-34. [CrossRef]

4. Zigmond, N.; Jenkins, J.; Fuchs, L.; Deno, S.; Fuchs, D.; Baker, J.; Jenkins, L.; Couthino, M. Special education in restructured schools: Findings from three multi-year studies. Phi Delta Kappan 1995, 76, 531-540.

5. York-Barr, J.; Duke, K. What do we know about teacher leadership? Findings from two decades of scholarship. Rev. Educ. Res. 2004, 74, 255-316. [CrossRef]

6. Muijs, D.; Harris, A. Teacher led school improvement: Teacher leadership in the UK. Teach. Teach. Educ. 2006, 22, 961-972. [CrossRef]

7. Ministry of Education (MOE). The National Education Strategy; MOE: Amman, Jordan, 2006.

8. Bennettet, N.; Wise, C.; Woods, P.A.; Harvey, J.A. Distributed Leadership; National College of School Leadership: Nottingham, UK, 2003.

9. DuFour, R. Work together: But only if you want to. Phi Delta Kappan 2011, 92, 57-61. [CrossRef]

10. Harris, A. Distributed Leadership: Different Perspectives; Studies in Educational Leadership; Springer: Berlin, Germany, 2009; Volume 7, pp. 241-243.

11. Murphy, J. Connecting Teacher Leadership and School Improvement; Corwin Press: Thousand Oaks, CA, USA, 2005.

12. Boyd-Dimock, V.; McGree, K.M. Leading Change from the Classroom: Teachers as Leaders. Available online: http:/ / www.sedl.org/change/issues/issues44.html (accessed on 27 June 2016).

13. Yarger, J.; Lee, O. The development and sustenance of instructional leadership. In Teachers as Leaders: Perspectives on the Professional Development of Teachers; Walling, D., Ed.; Phi Delta Kappa Educational Foundation: Bloomington, IN, USA, 1994; pp. 223-237.

14. Billingsley, B. Recognizing and supporting the critical roles of teachers in special education leadership. Exceptionality 2007, 15, 163-176. [CrossRef]

15. Powers, S.; Gregory, S.; Lynas, W.; McCracken, W.; Watson, L.; Boulton, A.; Harris, D. A review of good practice in deaf education. Deafness Educ. Int. 1999, 3, 139-141.

16. Smylie, A. Teachers' reports of their interactions with teacher leaders concerning classroom instruction. Elem. Sch. J. 1992, 93, 85-98. [CrossRef]

17. Johnson, M.; Donaldson, L. Overcoming the obstacles of leadership. Educ. Leadersh. 2007, 65, 32-41.

18. Barth, S. Teacher leader. Phi Delta Kappan 2001, 82, 443-449. [CrossRef]

19. Skrtic, M. Behind Special Education: A Critical Analysis of Professional Culture and School Organization; Love Publishing: Denver, CO, USA, 1991.

20. Sherrill, A. Preparing teachers for leadership roles in the 21st century. Theory Pract. 1999, 38, 56-61. [CrossRef]

21. Wasley, P. Teachers Who Lead: The Rhetoric of Reform and Realities of Practice; Teachers College Press: New York, NY, USA, 1991.

22. Pugach, M. Uncharted territory: Research on the socialization of special education teachers. Teach. Educ. Spec. Educ. 1992, 15, 133-147. [CrossRef]

23. Lieberman, A.; Saxl, E.; Miles, M. Teacher leadership: Ideology and practice. In The Jossey Bass Reader on Educational Leadership; Jossey Bass: San Francisco, CA, USA, 2000; pp. 339-345.

24. Embich, J. The relationship of secondary special education teachers' roles and factors that lead to professional burnout. Teach. Educ. Spec. Educ. 2001, 24, 58-69. [CrossRef]

25. Al-Natour, M.; Al-Zboon, E.; Alkhamra, H.; Amr, M. Examining Collaboration and Constraints on collaboration between special and general education teachers in mainstream schools in Jordan. Int. J. Spec. Educ. 2015, 30, 64-77.

26. Chirume, E. A Study of Educational Leadership: The Principals' and Teachers' Perceptions of Teacher Leadership Dynamics in Southeast Ohio. Ph.D. Thesis, Ohio University, Athens, OH, USA, 2008. 
27. Ngang, T. A comparative study on teacher leadership in special education classroom between China and Malaysia. Soc. Behav. Sci. 2012, 31, 231-235. [CrossRef]

28. Harris, A.; Muijs, D. Teacher Leadership: Principles and Practice; Institute of Education, University of Warwick: Coventry, UK; Warwick, MA, USA, 2003.

29. Pankake, A.; Moller, G. What the teacher leader needs from the principal. J. Staff Dev. 2007, 28, 35-46.

30. Petrovska, S.; Sivevska, D. How Macedonian educational context supports leadership role of elementary school teachers. Soc. Behav. Sci. 2014, 116, 4098-4102. [CrossRef]

31. York-Barr, J.; Sommerness, J.; Duke, K.; Ghere, G. Special educators in inclusive education programmes: Reframing their work as teacher leadership. Int. J. Incl. Educ. 2005, 9, 193-215. [CrossRef]

32. Kale, M.; Özdelen, M. The analysis of teacher leadership styles according to teachers' perceptions in primary schools. Soc. Behav. Sci. 2014, 152, 227-232. [CrossRef]

33. Toulabi, Z.; Raoufi, M.; Allahpourashra, Y. Investigating the relationship between teacher s' happiness and the components of working life quality. Soc. Behav. Sci. 2013, 84, 691-695. [CrossRef]

34. Qutaiba, A. The relationship between the level of school-involvement and Learned helplessness among special-education Arab-Palestinian teachers in Israel. Soc. Behav. Sci. 2010, 5, 1050-1057. [CrossRef]

35. Jarrar, A.; Shawareb, A. Factors Affecting Teachers' Excellence from the Perspective of Queen Rania Award-Winning Teachers: (A Jordanian Case). J. Educ. Pract. 2013, 4, 71-81.

36. Queen Rania Award for Educational Excellence Association QRA. Available online: http://www.queenrania. jo/en/initiatives/queen-rania-award-excellence-education (accessed on 28 June 2016).

37. Ministry of Education (MOE). Education Reform for Knowledge Economy Second Phase (ERfKE II): Annual Narrative Report; MOE, Development Coordination Unit: Amman, Jordan, 2013.

38. The World Bank. The Road Not Traveled: Education Reform in the Middle East and North Africa; The World Bank: Washington, DC, USA, 2008.

39. Ministry of Education (MOE). Ministry of Education's Projects in Jordan; MOE: Amman, Jordan, Unpublished work, 2014.

40. Thousand, J.; Nevin, A.; Villa, R. Collaborative teaching: Critique of the scientific evidence. In Handbook of Special Education Research; Florian, L., Ed.; Sage: London, UK, 2007; pp. 417-428.

41. Yeung, A. Exploring organisational perspectives on implementing educational inclusion in mainstream schools. Int. J. Incl. Educ. 2012, 16, 675-690. [CrossRef]

42. Abu-Hamour, B.; Al-Hmouz, H. Special education in Jordan. Eur. J. Spec. Needs Educ. 2014, 29, $105-115$. [CrossRef]

43. Yahia, K. Educational Programs for Individuals with Special Needs; Dar Al-Massira: Amman, Jordan, 2006.

44. Goor, M.; Schwenn, J.; Boyer, L. Preparing principals for leadership in special education. Interv. Sch. Clin. 1997, 32, 133-141. [CrossRef]

45. Guzman, N. Leadership for successful inclusive schools: A study of principal behaviours. J. Educ. Adm. 1997, 35, 439-450. [CrossRef]

46. Peters, S. Inclusive education in accelerated and professional development schools: A case-based study of two school reform efforts in the USA. Int. J. Incl. Educ. 2002, 6, 287-308. [CrossRef]

47. Lambert, L. Leadership redefined: An evocative context for teacher leadership. Sch. Leadersh. Manag. 2003, 23, 421-430. [CrossRef]

48. García, S.; Arbués, E. Leadership in teachers: A requirement for employability. Procedia Soc. Behav. Sci. 2014, 139, 565-571. [CrossRef]

49. Epanchin, B.; Colucci, K. The professional development school without walls. Remedial Spec. Educ. 2002, 23, 349-358. [CrossRef]

50. Powers, S.; Rayner, S.; Gunter, H. Leadership in inclusive education: A professional development agenda for special education. Br. J. Spec. Educ. 2001, 28, 108-113. [CrossRef]

51. Al-Zboon, E. Current Trends and Issues in Special Education; Dar Al-Fiker: Amman, Jordan, 2013.

52. Al-Zboon, E.; Dababneh, K.; Ahmad, J. Quality of work life: Perceptions of Jordanian special education teachers. Education 2015, 135, 380-388.

53. Institute for Educational Leadership. Leadership for Student Learning: Redefining the Teacher as Leader; Institute for Educational Leadership: Washington, DC, USA, 2001.

54. Creswell, J. Research Design: Qualitative, Quantitative, and Mixed Methods Approaches, 2nd ed.; Sage Publications: Thousand Oaks, CA, USA, 2003. 
55. Creswell, J.; Plano Clark, V. Designing and Conducting Mixed Methods Research, 2nd ed.; Sage: Thousand Oaks, CA, USA, 2011.

56. Andrews, A.; Frankel, E. Inclusive education in Guyana: A call for change. Int. J. Spec. Educ. 2010, 25, 126-144.

57. Strauss, A.; Corbin, J. Basics of Qualitative Research: Grounded Theory Procedures and Technique, 2nd ed.; Sage: Newbury Park, CA, USA, 1990.

58. Harris, A.; Jones, M. Professional learning communities and system improvement. Improv. Sch. 2010, 13, 172-181. [CrossRef]

59. Lieberman, A.; Miller, L. Teacher Leadership; Jossey-Bass: San Francisco, CA, USA, 2004.

60. Spillane, J.P.; Halverson, R.; Diamond, J.B. Towards a theory of leadership practice: A distributed perspective. J. Curric. Stud. 2004, 36, 3-34. [CrossRef]

61. Al-Natour, M. Special Needs Education, Program Development/Learning Disabilities; MOE: Amman, Jordan, 2008.

62. Cook, L.; Downing, J. The Practicalities of Collaboration in Special Education Service Delivery. Interv. Sch. Clin. 2005, 40, 296-300.

63. Hanuscin, D.; Rebello, C.; Sinha, S. Supporting the Development of Science Teacher Leaders-Where Do We Begin? Sci. Educ. 2012, 21, 12-18.

64. Silva, Y.; Gimbert, B.; Nolan, J. Sliding the doors: Locking and unlocking possibilities for teacher leadership. Teach. Coll. Rec. 2000, 102, 779-804. [CrossRef]

65. Mangin, M. Facilitating elementary principals' support for instructional teacher leadership. Educ. Adm. $Q$. 2007, 43, 33-44. [CrossRef]

66. Birky, D.; Shelton, M.; Headley, S. An administrator's challenge: Encouraging teachers to be leaders. Natl. Assoc. Second. Sch. Princ. Bull. 2006, 90, 87-101. [CrossRef]

67. Smylie, A.; Denny, W. Teacher consultantship: Tensions and ambiguities in organizational perspective. Educ. Adm. Q. 1990, 26, 235-259. [CrossRef]

68. Leithwood, K.; Seahore Louis, K.; Anderson, E.; Wahlstrom, K. How Leadership Influences Student Learning; Wallace Foundation: New York, NY, USA, 2004.

69. Gibb, G.; Welch, M. The Utah mentor teacher academy: Evaluation of a statewide mentor program. Teach. Educ. Spec. Educ. 1998, 21, 22-33. [CrossRef]

70. Harris, A. School Improvement: What's in It for Schools?; Falmer Press: London, UK, 2002.

71. Katyal, K.; Evers, C. Teacher Leadership: New Conceptions for Autonomous Student Learning in the Age of the Internet; Routledge: Oxon, UK, 2014.

72. Even, R. The Development of Teacher Leaders and in-service Teacher Educators. J. Math. Teach. Educ. 1999, 2, 3-24. [CrossRef]

73. Katkat, D. The leadership abilities teachers. Soc. Behav. Sci. 2014, 116, 3880-3885. [CrossRef]

74. Shakeshaft, C.; Nowell, I.; Perry, A. Gender and supervision. Theory Pract. 1991, 3, 134-139. [CrossRef]

75. Rosener, $\mathrm{B}$. The command-and-control leadership style associated with men is not the only way to succeed: Ways women lead. Harv. Bus. Rev. 1990, 68, 119-145. [PubMed]

76. Lather, P. Critical Frames in Educational Research: Feminist and Post-structural Perspectives. Theory Pract. 1992, 31, 87-99. [CrossRef]

77. Rutherford, C. Teacher leadership and organizational structure: The implications of restructured leadership in an Edison school. J. Educ. Chang. 2006, 7, 59-76. [CrossRef]

78. Lieberman, A. Teachers at the Forefront: Learning to Lead. In The Power of Teacher Leaders: Their Roles, Influence, and Impact; Bond, N., Ed.; Phi Delta Kappa Educational Foundation: Bloomington, IN, USA, 2015.

79. Driscoll, J. Practicing Clinical Supervision: A Reflective Approach for Healthcare Professionals, 2nd ed.; Bailliere Tindall Elsevier: Edinburgh, UK, 2007.

(C) 2016 by the author; licensee MDPI, Basel, Switzerland. This article is an open access article distributed under the terms and conditions of the Creative Commons Attribution (CC-BY) license (http://creativecommons.org/licenses/by/4.0/). 